\title{
Unilateral Cryptorchidism in Nigerian Sahel Bucks
}

\author{
Criptorquidia Unilateral en Cabras Sahel Nigerianas
}

\author{
"I. O. Igbokwe; "H. A. Grema; "A. E. Ikpo; "F. M. Mshelbwala \& **N. A. Igbokwe
}

\begin{abstract}
IGBOKWE, I, O.; GREMA, H. A.; IKPO, A. E.; MSHELBWALA, F. M. \& IGBOKWE, N. A. Unilateral cryptorchidism in Nigerian Sahel bucks. Int. J. Morphol., 27(3):805-810, 2009.

SUMMARY: Out of 1608 Nigerian Sahel male goats (bucks) examined for cryptorchidism in an abattoir, $9(0.6 \%)$ had right unilateral cryptorchidism. The coat colour-specific prevalence was highest among the brown bucks $(2.1 \%)$; and was $0.8 \%, 0.6 \%$, and $0.3 \%$ among black, white, back-and-white bucks, respectively. The condition was not found among bucks with brown-and-black, brownand-white, and multiple coat colours. The right and left testes of normal bucks and the descended testes of cryptorchid bucks had comparable gross testicular measurements, but the retained cryptorchid testes were smaller in size. The estimates of the testicular measurements showed that testicular weights (with the entire epididymes), peripheral longitudinal lengths and mid-circumferences of the cryptorchids were reduced by 5.8-6.5, 1.8-1.9, and 1.7-1.8 folds, respectively, when compared with the normal values; an indication that reduction in weight was the most remarkable index of change in testicular size. In 2 cases $(20 \%)$, cryptorchid testes were at a subcutaneous location, embedded in a subcutaneous fascia in the ventral perineal region, while in the other 8 cryptorchid cases ( $80 \%)$, the testes were in the abdomen. Histopathological changes in the cryptorchid testes included hypoplasia, degeneration, interstitial non-suppurative inflammation and fibroplasia. This is the first report of cryptorchidism in the Sahel goat and the first evidence that cryptorchid testis may be located subcutaneously in the goat.
\end{abstract}

KEY WORDS: Abdominal; Cryptorchidism; Goat; Hypoplasia; Morphometry; Nigeria; Sahel; Subcutaneous; Testis; Unilateral; Degeneration; Orchitis; Fibroplasia.

\section{INTRODUCTION}

Cryptorchidism is failure of one or both testes to descend from the foetal position in the sublumbar region through the inguinal canal into the scrotal sac. The condition is heritable and occurs where there is inbreeding over several generations, but some cases may be caused due to fetal exposure to estrogen, androgen inhibitors and certain endocrine disruptors (Thonneau et al., 2003; Amann \& Veeramachaneni, 2007). It may be unilateral or bilateral, but unilateral cryptorchidism occurs more frequently than bilateral cryptorchidism; and unilateral cryptorchidism is more common with the right than the left testis (Slatter, 1985; Foster, 2007). The position of the undescended testis may be subcutaneous (at the outlet of the inguinal ring or neck of the scrotum), inguinal or abdominal (Amann \& Veeramachaneni, 2007).

Cryptorchidism commonly affects horses, dogs, cats, pigs, cattle, but it is uncommon in sheep and goats (Arthur et al., 1983; Foster). A retained testis is most commonly located in the abdomen in dogs and horses, and the retained testis in the inguinal canal is more likely to be found in the horse than any other animal species (Amann \& Veeramachaneni, 2006). The prevalence of cryptorchidism in animals, reported as $0.1-12 \%$, excluded reference to prevalence in goats (Amann \& Veeramachaneni, 2007). However, the prevalence of the condition in feral goats in Australia and native goats in Iran were 1.1\% and 2.9\%, respectively (Tarigan et al., 1990; Kafi et al., 2007). In Southeastern Nigeria, unilateral cryptorchidism was reported in West African Dwarf (WAD) goats (Ezeasor, 1985; Emehelu et al., 2005; Wekhe et al., 2006) with a high prevalence of $70 \%$ in an area where persistent breeding with cryptorchid bucks occurred (Emehelu et al.).

The Nigerian Sahel (NS) goats are found in the northern semi-arid zones of the country (Bourn et al., 1994; 
Igbokwe et al., 1998) and differ from the WAD goats by being long-legged and adapted to the arid environment (Mason, 1984). There was no evidence that cryptorchidism occurred among NS goats until a goat seller in Maiduguri referred a cryptorchid buck to the Department in December, 2006. Subsequently, a preliminary survey of NS goats presented for slaughter at the metropolitan abattoir in Maiduguri, North-eastern Nigeria, was conducted for the prevalence and gross morphometry of the testes of the cryptorchid bucks.

\section{MATERIAL AND METHOD}

One cryptorchid NS buck referred to the Department of Veterinary Pathology, University of Maiduguri, Maiduguri, was examined ante-mortem and post-mortem after slaughter. A subsequent survey for cryptorchids among NS bucks presented for slaughter was conducted from March to April, 2007 at the metropolitan abattoir in Maiduguri, North-eastern Nigeria. The bucks were identified by coat colour, aged and weighed. The age was estimated by observing the dentition of the animals according to Chibuzo \& Sivachelvan (1994). Weight measurements were taken using a weighing machine (HANA, China) which was calibrated in kilograms. The cryptorchid and normal testes (with their epididymes) were collected from all cryptorchids and 20 randomly selected normal bucks of comparable age and weight, and weighed with a triple beam weighing ba- lance (OHAUS, USA) after cutting off the spermatic cord at the vascular cone and removing the tunica vaginalis. Other gross morphometric parameters of the testes, measured with a ruled measuring tape, were the peripheral longitudinal lengths and the mid-circumferences of the testes. The testes were sliced and fixed in $10 \%$ buffered formalin. The fixed tissues were processed, cut and stained with haematoxylin and eosin (Drury \& Wattington, 1976). The data were summarised as means \pm standard deviations and comparison of means was carried out using one-way analysis of variance and Student's t-test using computer software (GraphPad Instsat 1993 version, http://www.graphpadinstat.com).

\section{RESULTS}

Out of 1608 bucks examined for cryptorchidism, 9 $(0.6 \%)$ had right unilateral cryptorchidism. The coat colourspecific prevalence was highest among the brown bucks $(2.1 \%)$ and was $0.8 \%, 0.6 \%, 0.3 \%$ among black, white, backand-white bucks, respectively (Table I). The condition was not found among bucks with brown-and-black, brown-andwhite, and multiple coat colours. All the goats $(n=1608)$ were aged $1.9 \pm 0.4$ years and weighed $20.3 \pm 2.6 \mathrm{~kg}$, and there were no significant $(\mathrm{P}>0.05)$ variations in the ages and live body weights of the bucks with the various coat colours

The gross morphometry of the descended and retained testes of 8 cryptorchid bucks (aged $2.0 \pm 0.5$ years, weighing

Table I. Coat colour-specific prevalence of unilateral cryptorchidism among Nigerian Sahel bucks slaughtered in Maiduguri (March-April, 2007).

\begin{tabular}{lccc}
\hline Coat colour & Number of bucks & Number of cryptorchid & Prevalence (\%) \\
\hline Black & 121 & 1 & 0.8 \\
Brown & 142 & 3 & 2.1 \\
White & 685 & 4 & 0.6 \\
Black and White & 371 & 1 & 0.3 \\
Others & 289 & 0 & 0.0 \\
\hline Total & 1608 & 9 & 0.6 \\
\hline
\end{tabular}

Table II. Gross morphometry of the testes of normal and cryptorchid Nigerian Sahel bucks. a,b Mean \pm SD with different superscripts are significantly different $(\mathrm{P}<0.05)$. *Data of 8 out of 9 cryptorchid bucks were used.

\begin{tabular}{lcrc}
\hline & $\begin{array}{c}\text { Testicular } \\
\text { Longitudinal length }(\mathbf{c m})\end{array}$ & Circumference $(\mathbf{c m})$ & Weight $(\mathbf{g})$ \\
\hline Normal bucks $(\mathbf{n}=\mathbf{2 0})$ & $6.64+2.34^{\mathrm{a}}$ & $11.79+1.02^{\mathrm{a}}$ & \\
Right & $6.48+0.72^{\mathrm{a}}$ & $11.69+1.06^{\mathrm{a}}$ & $59.07+12.89^{\mathrm{a}}$ \\
Left & & & \\
Cryptorchid bucks* $(\mathbf{n}=\mathbf{8})$ & $6.13 \pm 1.66^{\mathrm{a}}$ & $10.69 \pm 5.69^{\mathrm{a}}$ & $54.23 \pm 8.63^{\mathrm{a}}$ \\
Descended & $3.45 \pm 0.79^{\mathrm{b}}$ & $6.40 \pm 4.24^{\mathrm{b}}$ & $9.36 \pm 3.37^{\mathrm{b}}$ \\
Retained & & & \\
\hline
\end{tabular}


$21.0 \pm 3.4 \mathrm{~kg}$ ) and the right and left testes of 20 normal bucks (aged $2.1 \pm 0.4$ years, weighing $23.1 \pm 3.4 \mathrm{~kg}$ ) within comparable ages and body weights are summarized in Table II. The right and left testes of normal bucks and the descended testes of cryptorchid bucks had comparable gross testicular measurements, but the retained cryptorchid testes were smaller in size. The mean testicular weight, peripherical longitudinal length and mid-circumference of the cryptorchids were reduced by 5.8-6.5, 1.8-1.9, and 1.7-1.8 folds, respectively, when compared with the normal means. The first cryptorchid we encountered in December, 2006 had the undescended testes at a subcutaneous location, embedded in a subcutaneous fascia in the ventral perineal region (Fig. 1, A). Seven of the 8 collected cryptorchid testes were located in the abdominal cavity, and one of them was subcutaneously located in the ventral perineum after the inguinal outlet (Fig. 1, B).
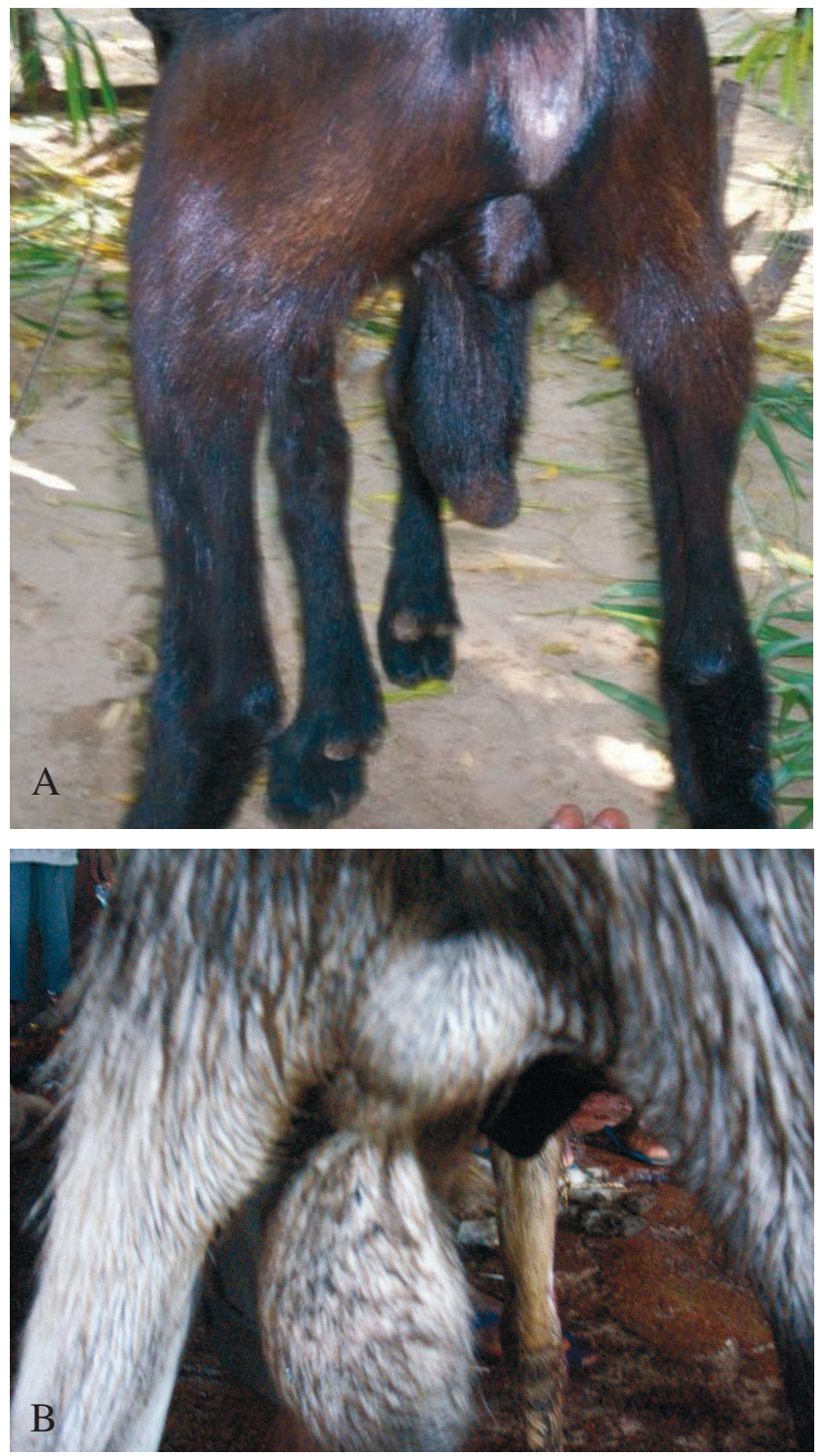

Fig. 1. Subcutaneous cryptorchid testes in two Nigerian Sahel bucks $(\mathrm{A}, \mathrm{B})$
The cryptorchid testes were visibly smaller than the scrotal testes (Fig 2) and soft to touch with smooth or pitted surfaces. Microscopically, the seminiferous tubules of the cryptorchid testis were hypoplastic with poorly differentiated germinal epithelium, with or without central hollow (Fig. 3, A) and in some testes, the tubules were separated by expanded areas of connective tissues. Some of the seminiferous tubules were severely degenerated and only thickened wavy basement membranes represented their locations in non-inflammatory and inflammatory areas (Fig $3, \mathrm{~B}, \mathrm{C})$. Interstitial non-suppurative orchitis involving degeneration and necrosis of the tubular epithelium and infiltration of the interstitial tissue by mononuclear cells was occasionally observed in cryptorchid testes (Fig. 3, D).

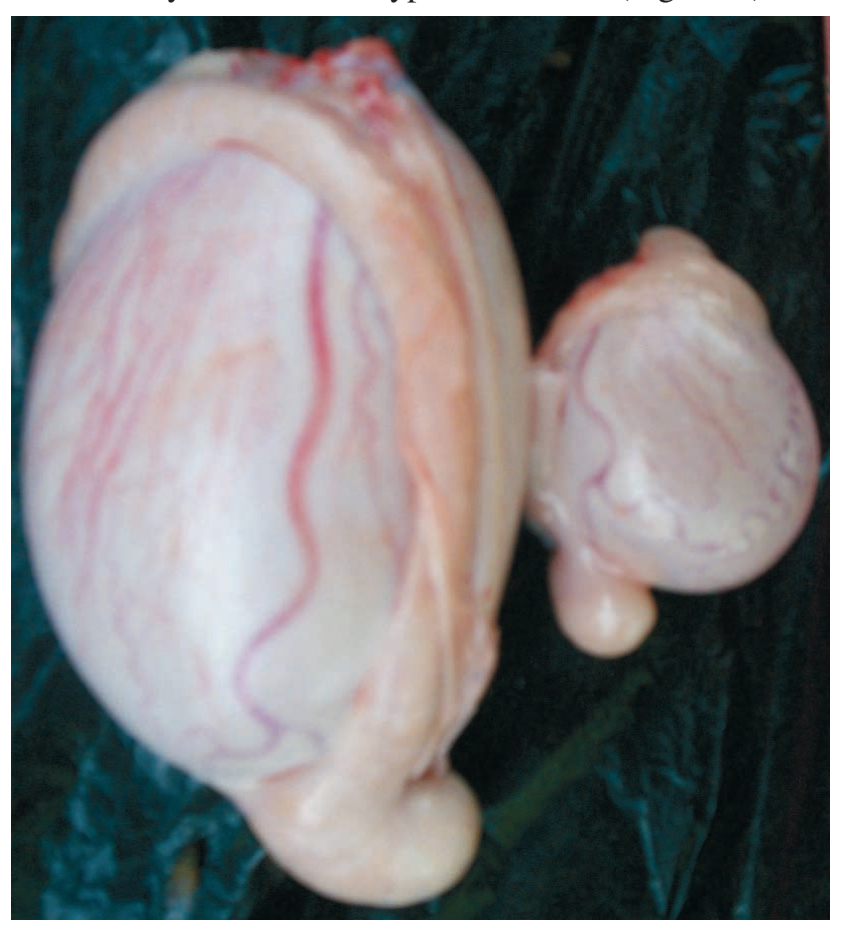

Fig. 2. A smaller cryptorchid testis (right unilateral) on the right and a normal scrotal testis on the left.

\section{DISCUSSION}

Recent panoramic reviews of cryptorchidism (Amann \& Veeramachaneni, 2006, 2007) failed to report the occurrence of the condition in goats. However, the prevalences of unilateral cryptorchidism in goats from Australia (Tarigan et al.) and Iran (Kafi et al.) were 1.1\% and $2.9 \%$, respectively. In Nigeria, unilateral cryptorchidism was very common (70\% prevalence) in WAD goats in the southeastern region (Ezeasor; Emehelu et al.), but it was relatively rare $(0.6 \%$ prevalence) in NS goats in the north-eastern region. The rarity of the condition might be responsible for 

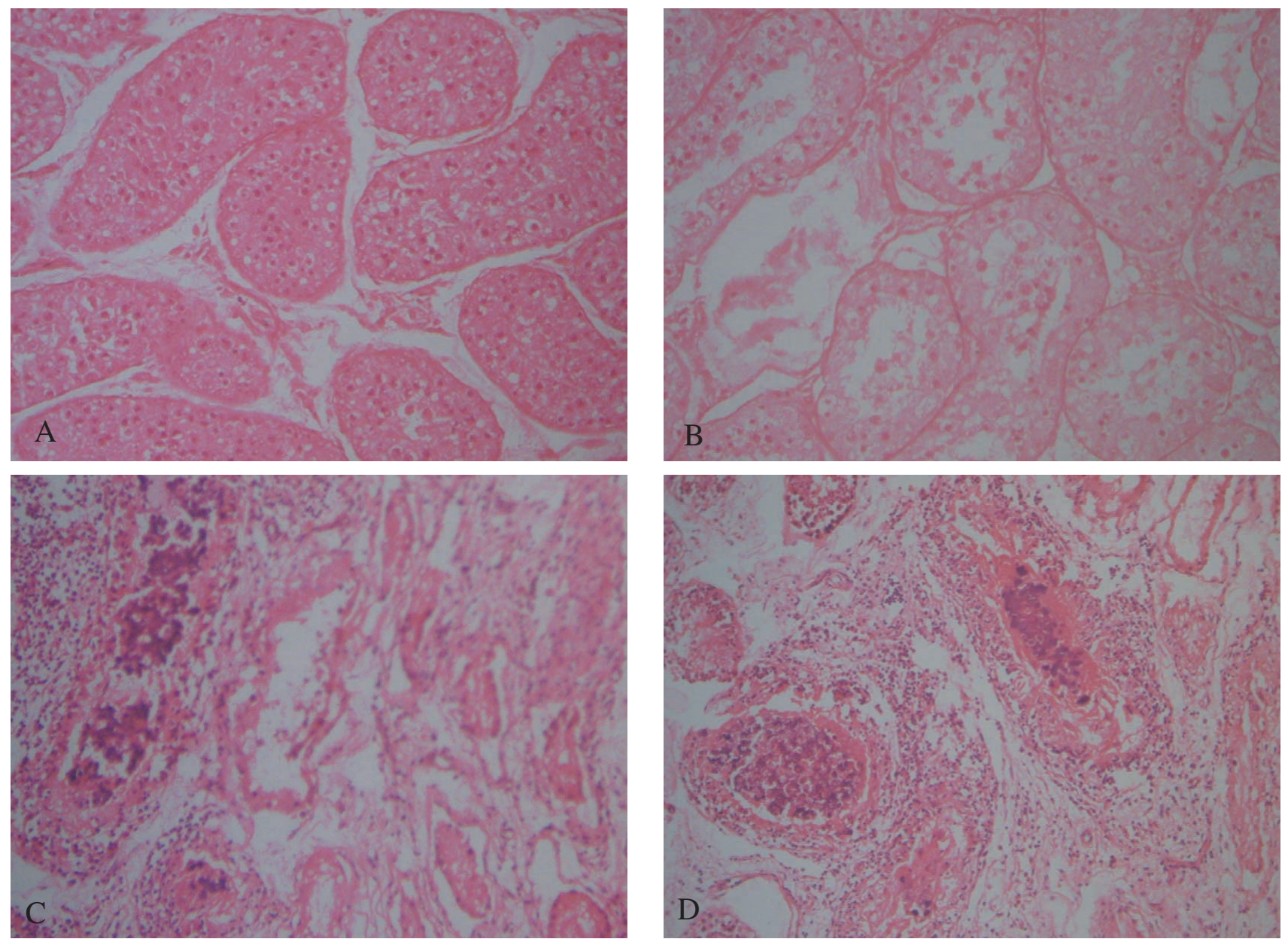

Fig. 3. Photomicrographs of the cryptorchid testis showing (A, B) hypoplastic seminiferous tubules with or without central hollow and increased degenration (Original x400), (C,D) interstitial orchitis in a cryptorchid testis showing necrosis of the tubular epithelial tissue, mononuclear cellular infiltration into the intertubular connective tissue, tubular atrophy and fibroplasia (Original x200).

the absence of any report of the condition earlier than now in our locality. Bilateral cryptorchidism has not been reported in bucks, but its occurrence in other animals is usually less common than that of unilateral cryptorchidism (Amann \& Veeramachaneni, 2007).

In WAD goats, the right testes was constantly being retained in the abdomen (Ezeasor), but based on ante-mortem examination, right and left testicular retentions occurred in $79.9 \%$ and $20.1 \%$ of 159 cases, respectively (Emehelu et al.), Similarly, Kafi et al. reported that right and left testicular retentions occurred in $66.7 \%$ and $33.3 \%$ of 12 cases, respectively. The testicular retention in NS goats were on the right side, an observation that was similar to previous reports (Ezeasor; Slatter)

The retained testes may be located in the abdomen, inguinal canal or at a subcutaneous location outside the external inguinal ring or near the neck of the scrotum (Amann
\& Veeramachaneni, 2007). Abdominal retention of the testes occurred in $80 \%$ of cases in NS cryptorchid bucks as compared to $100 \%$ in WAD (Ezeasor) and Iranian (Kafi et $a l$.) cryptorchid bucks. The subcutaneous testes (near the neck of the scrotum) observed in $20 \%$ of NS cryptorchid bucks had not been reported earlier among goats, but it was reported in humans, dogs, cats and horses (Amann \& Veeramachaneni, 2007). Subcutaneous retention of the testes is most common in humans where up to two-third of cases fully descend into the scrotum within 3 months after birth. After hypoplasia in the subcutaneous position, it was unlikely that the subcutaneous testes would correct its position in adult cryptorchid bucks.

The descended scrotal testis of the cryptorchid had comparable size with the scrotal testes of the normal buck, suggesting that the descended testis in the cryptorchid neither underwent compensatory hypertrophy nor atrophy under cryptorchid conditions. Thus, the cryptorchids were expected 
to be fertile as earlier reported (Zaidi et al., 2005), but some level of sub-fertility would be expected when they had been associated with decreased levels of serum testosterone (Hall \& Gomes, 1975) or when the spermatozoa had higher percentage of proximal cytoplasmic droplets and acrosomal defects (Baishya et al., 2003). The WAD cryptorchids were presumed by their owners to be more virile than the normal ones (Ezeasor) and were used for breeding resulting in high prevalence $(70 \%)$ of cryptorchidism among the WAD goats (Emehelu et al.). Similar breeding among NS goats with cryptorchids was unlikely.

The reduction in the size of the cryptorchid testis was measurable from the mid-circumference (MC), the peripheral longitudinal length (LL) and the weight of the testis (with the entire epididymes) (TW), but the difference in weight was more remarkable than the other measurements. The MC and LL of the cryptorchid testis were almost half of the normal measurements, while TW of the cryptorchid testis was one-sixth of the value for the descended testis. Kafi et al. reported that the weight of cryptorchid testis was approximately one-fourth of the weight of normal testis. The reduction in size of the cryptorchid testis is due to the smaller diameter of the hypoplastic, non-canalized seminiferous tubules devoid of spermatogenic cells, as presented in this report and in the report of Ezeasor. Degeneration of the hypoplastic seminiferous epithelium occurs because of dysgenetic changes (Foster). The inflammatory changes in the cryptorchid testes had not been previously reported in animals and its cause was unclear. Similar cases of focal orchitis had been reported in human cryptorchidism where it was associated with tubular ectasia and Sertoli cell dysgenesis, which probably caused alterations and disruption of the blood-testis barrier, and allowed antigens to enter the testicular interstitium, giving rise to an autoimmune process (Nistal et al., 2002).

In conclusion, this first report of unilateral cryptorchidism in NS goats (occurring in $0.6 \%$ of the population), provides the first evidence of subcutaneous retention of the testis in goats, the gross morphometric measurements to show the extent of reduction in size of the cryptorchid testis due to hypoplasia and the occurrence of inflammation in such testes.

\section{ACKNOWLEDGEMENTS}

The technical help of Alhaji Bukar (Department of Histopathology, UMTH, Maiduguri) in preparing the histopathology slides and assistance of the Maiduguri abattoir staff during the survey are sincerely appreciated.

IGBOKWE, I, O.; GREMA, H. A.; IKPO, A. E.; MSHELBWALA, F. M. \& IGBOKWE, N. A. Criptorquidia unilateral en cabras Sahel Nigerianas. Int. J. Morphol., 27(3):805-810, 2009.

RESUMEN: De las 1608 cabras Sahel Nigerianas macho examinadas para criptorquidismo en un matadero, $9(0,6 \%)$ tuvieron criptorquidia unilateral derecha. La prevalencia en relación al color específico del pelaje fue mayor entre las cabras marrones (2,1\%), y fue de $0,8 \%, 0,6 \%$ y $0,3 \%$ entre cabras de color negro, blanco, y blanco/negro respectivamente. La condición no fue encontrada entre las cabras con pelajes marrón y negro, marrón y blanco, y pelajes de múltiples colores. Los testículos derecho e izquierdo de las cabras normales y los testículos descendentes de las cabras con criptorquídia tuvieron mediciones testiculares comparables, pero los testículos retenidos por criptorquídia fueron de menor tamaño. Las estimaciones de las mediciones testiculares mostraron que los pesos testiculares (con todo el epidídimo), la longitud periférica y la circunferencia media de las criptorquídicas fueron reducidas por 5,8-6,5; 1,8-1,9 y 1,7-1,8 pliegues respectivamente, en comparación con el los valores normales; una indicación que la reducción de peso fue el índice de cambio más notable en el tamaño testicular. En 2 casos (20\%), los testículos criptorquídicos se encontraron en una ubicación subcutánea, inmersos en una fascia subcutánea en la región perineal ventral, mientras que en los otros 8 casos criptorquídicos (80\%), los testículos fueron encontrados en el abdomen. Cambios histopatológicos en los testículos criptorquídicos incluyeron hipoplasia, degeneración, inflamación intersticial no supurativa y fibroplasia. Este es el primer informe de criptorquidia en cabras Sahel y la primera evidencia de que los testículos criptorquídicos pueden ser localizados por vía subcutánea en la cabra.

PALABRAS CLAVE: Abdominal; Criptorquidia; Cabra; Hipoplasia; Morfometría; Nigeria; Sahel; Subcutánea; Testículo; Unilateral; Degeneración; Orquitis; Fibroplasia.

\section{REFERENCES}

Amann, R. P. \& Veeramachaneni, D. N. Cryptorchism and associated problems in animals. Anim. Reprod., 3:10820, 2006.
Amann, R. P. \& Veeramachaneni, D. N. Cryptorchidism in common eutherian mammals. Reproduction, 133:54161, 2007. 
Arthur, G. H.; Noakes, D. E. \& Pearson, H. Veterinary Reproduction and Obstetrics. $6^{\text {th }}$ Ed. London, Bailliere Tindall, 1983. pp.551-2.

Baishya, S. K.; Anubrata, D.; Khargharia, G. \& Bardoloi, R. K. Studies on certain aspects of epididymal spermatozoa of unilateral cryptorchid indigenous boar of Meghalaya. Indian J. Hill Farming, 16:86-8, 2003.

Bourn, D.; Wint, W.; Blench, R. \& Woolley, E. Nigerian livestock resources survey. World Anim. Rev., 78:49-58, 1994.

Chibuzo, G. A. \& Sivachelvan, M. N. Ruminant Dissection Guide: A Regional Approach in the Goat. Faculty of Veterinary Medicine, University of Maiduguri, 1994. pp.49-50.

Drury, R. A. B. \& Wallington, E. A. Carleton's Histological Techniques. $4^{\text {th }}$ Edn. London, Oxford University Press, 1976. pp.21-71.

Emehelu, C. O.; Ekwueme, E. C. \& Chah, K. F. Cryptorchidism in West African Dwarf goats in Nsukka agricultural zone of Enugu State, Nigeria. Sahel Journal of Veterinary Sciences, 4:59-60, 2005.

Ezeasor, D. N. Light and electron microscopical observations on the Leydig cells of the scrotal and abdominal testes of naturally unilateral cryptorchid West African dwarf goats. J. Anat., 141:27-40, 1985.

Foster, R. A. Male reproductive system. In: McGavin, M. D. \& Zachary, J. F. (eds.). Pathologic Basis of Veterinary Diseases, 4th Edn. St. Louis, Missouri, Mosby, 2007. pp.1317-48.

Hall, R. W. \& Gomes, W. R. The effect of artificial cryptorchidism on serum oestrogen and testosterone levels in adult male rat. Acta Endocrinol., 80:583-91, 1975.

Igbokwe, I. O.; Ribadu, A. Y. \& Bukar, M. M. Erythrocyte glutathione concentrations in Nigerian Sahel goats. Small Ruminant Res., 30:1-6, 1998.

Kafi, M.; Oryan, A. \& Morgan-Azghadi, N. Pathology of testis and epididymes in native goats in southern Iran. Comp. Clin. Pathol., 16:201-5, 2007.

Mason, I. L. Goat. In: Mason, I. L. (ed.). Evolution of Domestic Animals. England, Longman Group Ltd., 1984. pp.85-99.
Nistal, M.; Riestra, M. L. \& Paniagua, R. Discussion of pathologic mechanism of tubular atrophy. Arch. Pathol. Lab. Med., 126:64-9, 2002.

Slatter, D. Testis, epididymes and spermatic cord. In: Harry, W. B. (ed.). Textbook of Small Animal Surgery. Philadelphia, W. B. Saunders, 1985.

Tarigan, S.; Ladds, P. W. \& Foster, R. A. Genital pathology of feral male goats. Aust. Vet. J., 67:286-90, 1990.

Thonneau, P. F.; Candia, P. \& Mieusset, R. Cryptochidism: incidence, risk factors, and potential role of environment; an update. J. Androl., 24:155-62, 2003.

Wekhe, S. N.; Berepubo, N. A.; Oruwari, B. M. \& Ogburia, M. G. X-Chromatin (drumstick) status of a male West African Dwarf goat with unilateral cryptorchidism: a case report. Sahel Journal of Veterinary Sciences, 5:25-7, 2006.

Zaidi, M. T.; Khan, A. A. \& Faruqi, N. A. Microstructure of the spermatic system in a fertile unilateral crypyorchid male- a case report. J. Anat. Soc. India, 54:1-9, 2005.

Correspondence to:

I. O. Igbokwe

Department of Veterinary Pathology

Faculty of Veterinary Medicine

University of Maiduguri, P.M.B. 1069

Maiduguri

NIGERIA

Tel: +2348034811622

Email: ikeigbokwe@gmail.com

Received: 13-01-2009

Accepted: 16-04-2009 